\title{
Hak Atas Air dan Kewajiban Negara dalam Pemenuhan Akses terhadap Air
}

\author{
1) ARINTO NURCAHYONO, 2) HUSNI SYAM, 3) YUHKA SUNDAYA \\ 1) 2) Fakultas Hukum, Universitas Islam Bandung, Jl. Rangga Gading 8 Bandung 40116 \\ 3) Fakultas Ekonomi dan Bisnis, Universitas Islam Bandung, Jl. Tamansari No.1 Bandung 40116 \\ email: ${ }^{1)}$ artnur@gmail.com ; 2) mhsyam@gmail.com ; ${ }^{3)}$ yuhkas@yahoo.com
}

\begin{abstract}
Water is a basic need of human being, no one can live without water and it has no substitution. Water is a a requirement of adequate living standard for the health and well-being of all human being.. The current problem is the availability of water in fulfill the human need is decreased. On the one hand there is the view that water is a commodity while the other side said that water is a social good.. The right to water implies that everyone should have access to water without discrimination. The state's role is indispensable when people are not in the same position in getting water, the differences position of people can occur not only a problem of economic inequality, but also the specific natural conditions in a certain region. Such differences make some parts of society difficult to gain access to water, and in this situation, the presence of the state is strong required.
\end{abstract}

Key words: basic need, right of water, state role.

\begin{abstract}
Abstrak. Air merupakan kebutuhan dasar manusia, tidak ada seorangpun yang bisa hidup tanpa air dan bukan benda yang memiliki substitusi. Sebagai kebutuhan dasar, air merupakan bagian dari persyaratan standar hidup yang memadai untuk kesehatan dan kesejahteraan semua manusia. Permasalahan yang dihadapi saat ini adalah ketersediaan air dalam memenuhi kebutuhan manusia yang jumlahnya semakin menurun. Di satu sisi ada pandangan bahwa air adalah suatu komoditas (economic good) sementara sisi lain mengatakan bahwa air merupakan social good. Hak atas air menyiratkan bahwa setiap orang harus memiliki akses ke air tanpa diskriminasi. Peran negara sangat diperlukan ketika orang tidak berada dalam dalam posisi yang sama dalam mendapatkan air, perbedaan posisi setiap orang tersebut tidak hanya karena adanya masalah ketimpangan ekonomi, tetapi juga kondisi alam yang ada di suatu wilayah tertentu. Perbedaan tersebut membuat beberapa bagian dari masyarakat sulit untuk mendapatkan akses ke air, dan dalam situasi ini, kehadiran negara sangat diperlukan.
\end{abstract}

Kata kunci: kebutuhan dasar, hak atas air, peran negara.

\section{Pendahuluan}

Air dalam sejarah kehidupan manusia memiliki posisi sentral dan merupakan jaminan keberlangsungan kehidupan manusia di muka bumi. Air berhubungan dengan hak hidup sesesorang sehingga air tidak bisa dilepaskan dalam kerangka hak asasi manusia. Pengakuan air sebagai hak asasi manusia mengindikasikan dua hal; di satu pihak adalah pengakuan terhadap kenyataan bahwa air merupakan kebutuhan yang demikian penting bagi hidup manusia, di pihak lain perlunya perlindungan kepada setiap orang atas akses untuk mendapatkan air. Demi perlindungan tersebut perlu diposisikan hak atas air menjadi hak yang tertinggi dalam bidang hukum yaitu hak asasi manusia.

Dalam makalah ini akan dirumuskan, pertama, bagaimanakah penjabaran hak atas air sebagai hak asasi manusia, baik dalam konteks Islam, Instrumen Hukum Internasional serta dalam perundanganundangan nasional? Kedua, bagaimana implikasi penguasaan air oleh swasta secara

Received: 30 Juni 2015, Revision: 10 September 2015, Accepted: 18 Desember 2015

Print ISSN: 0215-8175; Online ISSN: 2303-2499. Copyright@2015. Published by Pusat Penerbitan Universitas (P2U) LPPM Unisba Terakreditasi SK Kemendikbud, No.040/P/2014, berlaku 18-02-2014 s.d 18-02-2019 
eksklusif terhadap pemenuhan hak atas air?, Ketiga, bagaimanakah negara melakukan kewajibannya dalam pemenuhan hak atas air?

\section{Pembahasan}

Hak atas air merupakan hak asasi yang bukan datang dari negara, konteks ekologis tertentu dari eksistensi manusialah yang memunculkan hak atas air (Maude Barlow, 2003:23). Oleh karena itu, masuknya negara dalam pengelolaan air sebagai wujud hak menguasai yang terdapat dalam Pasal 33 ayat (3) UUD NRI 1945 merupakan bentuk perlindungan hak-hak asasi tersebut agar dapat terjaga dan terjamin bagi seluruh rakyat, yang tidak dapat dihilangkan oleh siapapun, karena hak atas air merupakan hak yang bersifat kodrati, sehingga jelas bahwa air sebagai kebutuhan manusia merupakan hak yang harus dipenuhi oleh negara sebagai bentuk pengakuan terhadap hak untuk hidup itu sendiri.

Oleh karena itu, keberadaan Pasal 33 ayat (3) UUD NRI 1945 secara filosofis merupakan penjelmaan Sila ke-5 Pancasila yaitu Keadilan bagi Seluruh Rakyat Indonesia, dimana air sebagai salah satu kekayaan nasional merupakan kebutuhan rakyat yang dikuasai negara dalam kerangka memberikan keadilan dan kesejahteraan bagi seluruh rakyat Indonesia (Wiwik Harjanti, 2009).

\section{Air dalam Perspektif Islam}

Al-Qur'an, sebagai fondasi agama Islam, menyatakan bahwa air merupakan hal paling penting bagi keberlangsungan hidup seluruh makhluk di muka bumi sekaligus bumi itu sendiri. Dalam Surat An Nahl, 65: dikatakan Dan Allah menurunkan dari langit air (hujan) dan dengan air itu dihidupkanNya bumi sesudah matinya. Sesungguhnya pada yang demikian itu benar-benar terdapat tanda-tanda (kebesaran Tuhan) bagi orangorang yang mendengarkan (pelajaran).

Pernyataan ayat ini ("dengan air itu dihidupkan-Nya bumi sesudah matinya") cukup gamblang menjelaskan, tanpa diperlukan metode penafsiran, setidaknya tentang dua informasi mengenai esensi air. Pertama adalah fungsi air sebagai unsur keberlangsungan makhluk hidup, sebagaimana sudah dijelaskan sebelumnya. Informasi kedua adalah mengenai apa yang disebut sebagai teori daur hidrologi air dewasa ini. Hal tersebut ditunjukkan dalam kalimat "...Allah menurunkan air dari langit, lalu diaturnya menjadi sumbersumber air di bumi...". Pernyataan ini mengandung kesimpulan bahwa air yang ada di muka bumi ini merupakan satu kesatuan yang tidak terpisahkan, yang juga berimplikasi terhadap hukum tentang pengaturan air dalam kehidupan manusia.

Dalam pandangan Islam, kepemilikan terhadap sumber daya alam yang ada di bumi pada dasarnya ialah milik Allah Swt(QS. Al-Nuur: 33). Kepemilikan yang ada pada Allah pada dasarnya ialah semata untuk menciptakan kesejahteraan dan keadilan bagi segenap manusia. Untuk mengatur penggunaan kepemilikan tersebut di muka bumi, Allah mengaturnya lewat pesan universal Al-Qur'an dan pesan-pesan RasulNya, seperti yang ada dalam Hadis atau Sunnah. Pesan Al-Qur'an dan Hadis inilah yang kemudian melahirkan ijtihad ulama'.

Hak kepemilikan sumber daya alam dalam Islam ditegaskan sangat spesifik dalam sebuah Hadis yang berbunyi:

"Kaum Muslim bersekutu (memiliki hak yang sama) dalam tiga hal: air, padang rumput dan api" (HR Abu Dawud, Ahmad dan Ibnu Majah).

Alasan mendasar dari eksistensi kepemilikan ketiga hak tersebut (air, padang, rumput dan api) karena manfaat hak ketiganya yang berkaitan dengan hajat hidup orang banyak. Peniadaan terhadap hakhak publik tersebut akan mendorong terhadap kemiskinan, pemelaratan dan kemudaratan. Privatisasi terhadap ketiga hak tersebut berarti akan meniadakan hak-hak publik untuk menggunakan dan mengonsumsinya. Berkaitan dengan dimensi publik seperti di atas juga, Rasulullah Saw pada suatu kesempatan bersabda :

"Bahwa ia datang kepada Rasulullah saw meminta (tambang) garam, maka beliau pun memberikannya. Setelah ia pergi ada seorang laki-laki yang bertanyakepada beliau, "Wahai Rasulullah, tahukah apa yang engkau berikan kepadanya? Sesungguhnya engkau telah memberikan sesuatu yang bagaikan air mengalir. Lalu ia berkata: Kemudian Rasulullah saw pun manarik kembali tambang itu darinya" (HR Abu Dawud).

Sebab-sebab kehadiran hadis ini dijelaskan oleh Abu Ubaid. Ia mengatakan Pemberian Nabi Saw kepada Abyadh bin Hambal terhadap tambang garam yang terdapat di daerah Ma'rab, yang kemudian beliau mengambilnya kembali dari tangan Abyadh. Sesungguhnya Rasulullah mencabutnya semata karena menurut beliau, tambang tersebut merupakan tanah 
mati yang dihidupkan oleh Abyadh, lalu dia mengelolanya.

Ketika Nabi Saw mengetahui bahwa tambang tersebut (laksana) air yang mengalir, yang mana air tersebut merupakan benda yang tidak pernah habis, seperti mata air dan air bor, maka beliau mencabutnya kembali, karena sunnah Rasulullah Saw dalam masalah padang, api, dan air menyatakan bahwa semua manusia berserikat dalam masalah tersebut, maka beliau melarang bagi seseorang untuk memilikinya, sementara yang lain tidak dapat memilikinya.

Sebagai manusia beriman, selayaknya manusia menjadikan keimanan sebagai panduan sikap dan perilaku sehari-hari, termasuk sikap manusia terhadap air. Sejak awal kemunculannya di dunia arab sekitar 14 abad yang lampau, Islam telah mengajarkan dan memerintahkan umatnya untuk menjaga kesucian. Tidak hanya itu, Al Quran dan hadis secara khusus memberi panduan berkaitan dengan penggunaan air. Dalam ayat-ayat Al Quran, Allah menegaskan kesesalinghubungan seluruh makhluk sehingga dikatakan bahwa mencederai seorang manusia sama dengan mencederai seluruh manusia. Dikaitkan dengan penegasan ayat Al Quran ini berarti jika seorang manusia membatasi atau menahan seseorang untuk mengambil haknya atas air, berarti dia telah mengusik dan merusak kemanusiaan. Jika ada pembatasan akses terhadp air berarti manusia telah melakukan kerusakan dan keburukan (Ibrahim AbdulMartin, 2010:182-184)

\section{Hak Atas Air dalam Instrumen Inter- nasional}

Diawali pada tahun 1948, ketika Deklarasi Universal Hak Asasi Manusia (DUHAM) dideklarasikan dan dilanjutkan pada tahun 1966, dengan pemberlakuan International Covenants on Economic, Social and Cultural Rights (ICESCR) dan International Covenant on Civil and Political Rights (ICCPR), dan disana air tidak disebut eksplisit sebagai hak asasi tetapi disebutkan sebagai bagian tidak terpisahkan dari hak asasi yang telah disepakati yaitu hak untuk hidup, hak untuk kehidupan yang layak, hak untuk kesehatan, hak untuk perumahan dan hak untuk makanan.

Setelah itu, barulah disebutkan secara lebih eksplisit walaupun masih sebagai bagian dari suatu konvensi dengan tema lain seperti misalnya yang tertuang dalam pasal
14, ayat (2), huruf $h$, Th Convention on the Elimination all of Forms Discrimination Against Women-(CEDAW 1979), bahwa negara pihak harus mengambil langkah-langkah yang terukur untuk menghapuskan berbagai bentuk diskriminasi terhadap perempuan, khususnya menjamin hak-hak perempuan untuk menikmati standar kehidupan yang layak atas sanitasi dan air minum yang sehat.

Demikian juga dalam pasal $24 \mathrm{Th}$ Convention on Th Right of Th Child-CRC 1989 yang menyatakan bahwa dalam upaya mencegah malnutrisi dan penyebaran penyakit maka setiap anak memiliki hak atas air minum yang bersih. Kemudian dilanjutkan dengan pernyataan dan himbauan melalui Deklarasi Millenium yang mencetuskan proyek MDGs (Millenium Development Goals), yang merupakan komitmen para kepala negara/ pemerintahan anggota PBB untuk memerangi kemiskinan global antara 2000-2015.

Deklarasi MDGs menyerukan kepada pemerintah agar "menyediakan akses air bersih dan sanitasi yang memadai bagi masyarakat yang saat ini belum bisa menikmatinya." Tetapi pernyataan yang eksplisit dan secara khusus menyebut air baru terjadi pada tahun 2002, ketika Komite Hak Ekonomi Sosial dan Budaya PBB dalam komentar umum Nomor 15 memberikan penafsiran yang lebih tegas terhadap pasal 11 dan 12 Konvensi Hak Ekonomi, Sosial dan Budaya yang menyatakan hak atas air tidak bisa dipisahkan dari hak-hak asasi manusia lainnya, yaitu air tidak hanya sebagai komoditas ekonomi dan akses terhadap air (right to water) adalah hak asasi manusia. The human right to water entitles everyone to suffiient, affrdable, physically accessible, safe and acceptable water for personal and domestic uses. Hak atas air juga termasuk kebebasan untuk mengelola akses atas air.

Elemen hak atas air harus mencukupi untuk martabat manusia, kehidupan dan kesehatan. Kecukupan hak atas air tidak bisa diterjemahkan dengan sempit, hanya sebatas pada kuantitas volume dan teknologi. Air harus diperlakukan sebagai barang sosial dan budaya, tidak semata-mata sebagai barang ekonomi.

Komentar Umum 15 (2002) Hak Atas Air (Pasal 11 dan 12 Kovenan Internasional Hak-Hak Ekonomi, Sosial, dan Budaya) menegaskan bahwa:

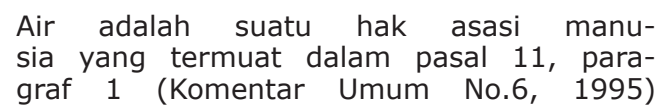
graf 1 (Komentar Umum No.6, 1995) 
Hak asasi manusia atas air memberikan hak kepada setiap orang atas air yang memadai, aman, bisa diterima, bisa diakses secara fisik dan mudah didapatkan untuk penggunaan personal dan domestik. Jumlah air bersih yang memadai diperlukan untuk mencegah kematian karena dehidrasi, untuk mengurangi risiko penyakit yang berkaitan dengan air, serta digunakan untuk konsumsi, memasak, dan kebutuhan higienis personal dan domestik.

Hak atas air secara jelas masuk dalam kategori jaminan mutlak untuk memenuhi standar kehidupan yang layak, khususnya karena hak ini adalah salah satu kondisi yang paling fundamental untuk bertahan hidup. bahwa air adalah suatu hak asasi manusia yang termuat dalam pasal 11, paragraf 1 . (Komentar Umum No.6, 1995).

Hak atas air juga merupakan tak bisa dilepaskan dari hak untuk mendapatkan standar kesehatan tertinggi.

Menjamin kepada perempuan hak untuk "menikmati kondisi hidup yang layak, terutama dalam kaitan dengan [...] suplai air" (CEDAW, 1979).

Berkaitan dengan Hak Anak, negara berkewajiban untuk memerangi penyakit dan kekurangan gizi "melalui pengaturan tentang makanan bergizi dan air minum yang layak". (CRC, 1979).

Air dibutuhkan untuk tujuan yang berbeda-beda, selain penggunaan personal dan domestik,untuk merealisasikan bermacammacam hak yang ada dalam Kovenan. Misalnya, air dibutuhkan untuk memproduksi makanan (hak atas bahan pangan yang layak) serta menjamin hieginitas lingkungan (hak atas kesehatan). Air sangat dibutuhkan untuk menjamin standar kehidupan (hak untuk mandapatkan nafkah dengan bekerja) dan untuk menikmati praktik-praktik budaya tetentu (hak untuk mengambil bagian dalam kehidupan budaya).

Meski demikian, prioritas alokasi air harus diberikan kepada hak atas air untuk penggunaan personal dan domestik. Prioritas juga harus diberikan kepada sumber daya air yang dibutuhkan untuk mencegah kelaparan dan penyakit, juga yang dibutuhkan untuk memenuhi kewajiban inti dari setiap hak yang diatur dalam Kovenan (Johannesburg Declaration on Sustainable Development, 2002).

Adapun dalam komentar umum disebutkan pula muatan normatif hak atas air yang terdiri dari:

Pertama, hak atas air berisikan kebebasan-kebebasan dan hak-hak. Kebebasan ini termasuk hak untuk menjaga akses kepada suplai air yang ada yang dibutuhkan untuk terpenuhinya hak atas air, dan hak untuk bebas dari gangguan, seperti hak untuk bebas dari pemutusan sewenang-wenang atau kontaminasi suplai air. Sebaliknya, "hak" termasuk hak atas sistem suplai dan manajemen air yang memungkinkan kesempatan yang sama bagi setiap orang untuk menikmati hak atas air.

Kedua, Unsur-unsur hak atas air harus memadai bagi martabat, kehidupan dan kesehatan manusia, sesuai dengan pasal 11 paragraf 1 dan pasal 12. Kelayakan air tidak bisa diartikan secara sempit, dengan mengacu hanya pada kuantitas dan teknologi yang digunakan. Air harus diperlakukan sebagai suatu barang sosial dan budaya, tidak hanya sebagai barang ekonomis. Pemenuhan hak atas air juga harus bersifat berkelanjutan, menjamin bahwa hak tersebut dapat terus dipenuhi untuk generasi sekarang dan yang akan datang.

Meskipun kelayakan air tersebut bisa berbeda-beda sesuai dengan situasinya, faktor-faktor berikut ini berlaku di semua kesempatan (Catarina de Albuquerque, 2014:29-32):

Persediaan. Suplai air untuk setiap orang harus memadai dan kontinyu untuk penggunaan personal dan domestik. Penggunaan-penggunaan ini biasanya termasuk minum, sanitasi personal, cuci pakaian, penyiapan makanan, kebersihan personal dan rumah tangga.

Kualitas. Air yang dibutuhkan untuk penggunaan personal dan domestik harus aman, oleh karena itu harus bebas dari mikro organisme, substansi kimia, dan bahaya radiologis yang membahayakan kesehatan manusia. Lebih lanjut, air tersebut harus mempunyai warna, bau dan rasa yang bisa diterima bagi penggunaan personal dan domestik.

Aksesibilitas. Air serta fasilitas dan layanan pengairan harus bisa diakses oleh setiap orang tanpa diskriminasi, di seluruh wilayah negara penandatangan. Aksesibilitas mempunyai empat dimensi yang saling berkaitan :

Aksesibilitas fisik; air, dan fasilitas dan 
layanan pengairan yang memadai, harus berada dalam jangkauan fisik yang aman bagi semua bagian masyarakat. Air yang memadai, aman dan bisa diterima harus bisa diakses dari, atau berada di sekitar, setiap rumah tangga, lembaga pendidikan atau tempat kerja. Seluruh fasilitas dan layanan pengairan harus mempunyai kualitas memadai, layak secara budaya, sensitif terhadap gender, daur ulang dan kebutuhan privasi. Keamanan fisik tidak boleh diganggu selama akses kepada fasilitas dan layanan pengairan.

Aksesibilitas Ekonomis: Air, dan fasilitas serta layanan pengairan, harus terjangkau (biayanya) oleh setiap orang. Biaya langsung maupun tak langsung serta tagihan yang berkaitan dengan jaminan pengairan harus terjangkau, dan tidak boleh membahayakan realisasi hak-hak lain yang diatur dalam Kovenan.

Non Diskriminasi : Air, dan fasilitas serta layanan pengairan harus bisa diakses oleh semua orang, termasuk pihak-pihak yang paling rentan atau termarjinalisasi dalam masyarakat, secara hukum dan secara nyata, tanpa diskriminasi atas dasar-dasar yang terlarang; dan

Aksesibilitas informasi : Aksesibilitas termasuk hak untuk mencari, menerima dan memberikan informasi mengenai masalah air.

Selanjutnya, dalam kerangka pemenuhan hak atas air dalam komentar umum Komentar Umum 15 (2002) Hak Atas Air disebutkan adanya kewajiban negara dalam pemenuhan hak atas air yakni : Pertama, untuk menjamin akses kepada jumlah air minimal, yang memadai dan aman bagi penggunaan personal dan domestik untuk mencegah penyakit; Kedua, untuk menjamin bahwa hak atas akses kepada air dan fasilitas dan layanan pengairan tidak diskriminatif, terutama untuk kelompok yang kurang beruntung atau termarjinalisasi; Ketiga, untuk menjamin akses fisik kepada fasilitas dan layanan pengairan yang memberikan air yang memadai, aman dan rutin; yang mempunyai jumlah outlet air yang cukup untuk menghindari waktu tunggu yang terlalu lama; dan yang berjarak cukup dekat dari rumah tangga; Keempat, untuk mnjamin bahwa keamanan personal tidak terganggu ketika melakukan akses fisik kepada air; untuk menjamin distribusi yang adil dari semua fasilitas dan layanan pengairan dan Kelima, untuk menetapkan dan mengimplementasikan suatu strategi pengairan nasional dan suatu rencana aksi yang ditujukan bagi seluruh populasi. Strategi dan rencana aksi tersebut harus direncanakan dengan baik, dan ditinjau secara periodik, dengan landasan proses yang partisipatif dan transparan, hal tersebut harus termasuk metode-metode, seperti hak atas indikator dan tolok ukur pengairan, yang dengannya kemajuan bisa dipantau dengan cermat.

Tahun 1977 Konferensi International PBB yang pertama tentang air diselenggarakan di Mar del Plata, Argentina. Konferensi tersebut mengeluarkan sebuah resolusi yang salah satunya berbunyi:

"All peoples, whatever their stage of development and their social and economic conditions, have the right to have access to drinking water in quantities and of a quality equal to their basic needs". (United Nations Water Conference, 1977).

Konvensi tersebut mewajibkan pemerintah untuk mengambil seluruh langkah dalam menjamin kehidupan yang layak termasuk ketersediaan sarana air bersih. Selain itu juga mengatur hal-hal teknis mengenai pembagian sumber air. Konferensi mengharuskan adanya manajemen pembagian sumber air yang menyangkut program, perlengkapan dan institusi sebagai upaya koordinasi di antara negara-negara yang berbagi. Solusi tersebut dapat pula dilakukan dengan pendekatan "permasalahan global harus diselesaikan dengan solusi global". Karena kelangkaan air di suatu tempat tentu akan memberikan efek negatif ke beberapa tempat di sekitarnya (Amy Hardberger, 2006: 564).

\section{Kewajiban Negara dalam Pemenuhan Akses terhadap Air}

Pengakuan akses terhadap air sebagai hak asasi manusia mengindikasikan dua hal; di satu pihak adalah pengakuan terhadap kenyataan bahwa air merupakan kebutuhan yang demikian penting bagi hidup manusia, di pihak lain perlunya perlindungan kepada setiap orang atas akses untuk mendapatkan air.

Demi perlindungan tersebut perlu dipositifkan hak atas air menjadi hak yang tertinggi dalam bidang hukum yaitu hak asasi manusia. Permasalahan yang timbul kemudian adalah bagaimana posisi negara dalam hubungannya dengan air sebagai benda publik atau benda sosial yang bahkan telah diakui sebagai bagian dari hak asasi manusia. 
Sebagaimana hak-hak asasi manusia lainnya posisi negara dalam hubungannya dengan kewajibannya yang ditimbulkan oleh hak asasi manusia, negara harus menghormati (to respect), melindungi (to protect), dan memenuhinya (to fulfill);

Berkaitas dengan istilah the right to water dalam bahasa Ingris dikenal dua istilah untuk hak atas air yaitu water right dan the right to water. Sekalipun secara gramatikal tidak ada perbedaan, tetapi secara teknis hukum dua istilah itu memiliki sejarah dan tradisi hukum yang berbeda. Water Right berasal dari tradisi hukum kepemilikan (property right) yang mengakui adanya hak kepemilikan manusia terhadap benda-benda tertentu. Bahkan nantinya, hasil daya nalar juga dapat disetarakan dengan hak ini.

Sebagaimana hak kepemilikan lainnya, maka water right juga bersifat exclusive, monopoly dan dapat dipertukarkan (tradable). Sifat eksklusif berarti bahwa jika ada seseorang sudah mendapatkan hak ini maka tidak ada orang lain yang berhak mengklaim hak yang sama atas benda yang sama. Hak atas tanah adalah contoh yang mudah dimengerti (www. kruha.org diakses 20 Agustus 2014).

Di dalam the right to water yang mengikuti tradisi hukum hak asasi manusia (HAM). Tradisi hukum HAM justru mengenalkan sifat yang bisa dikatakan berbeda kalau tidak bertentangan. Sifat yang melingkupi dalam HAM adalah inclusive, universal, dan inalienable. Sifat inklusif membuat hak ini dapat dimiliki secara pribadi sekaligus juga bersama-sama oleh semua orang. Klaim seseorang atas hak ini tidak membuat orang lain kehilangan klaim atas hak ini. Universalitas dari hak ini juga ditunjukkan dengan pengakuan yang dilakukan oleh masyarakat dunia. Dalam banyak hak tidak dibutuhkan perlakuan khusus sehingga hak ini bisa dimiliki. Setiap manusia secara otomatis dapat memiliki hak ini. Sejalan dengan itu, maka sifat ketiga dari hak ini yang tidak dapat dipisahkan membuat hak ini juga tidak bisa dipertukarkan atau diperjualbelikan. (www.kruha.org diakses 20 Agustus 2014).

Perumusan dan perencanaan strategi nasional atas air dan rencana aksi nasional (termasuk juga hukum dan kebijakan) harus berdasarkan pada konsep pembangunan berbasis hak yang menempatkan orang tidak hanya sebagai penerima tetapi sebagai pusat dari pembangunan. Pembangunan berbasis hak merupakan kerangka kerja konseptual untuk pembangunan yang berdasar pada standar internasional hak asasi manusia dan dalam pelaksanaannya mempromosikan dan melindungi hak asasi manusia. Pendekatan berbasis hak mengintegrasikan norma, standar dan prinsip yang ada dalam sistem internasional hak asasi manusia kedalam perencanaan, kebijakan dan proses pembangunan. Pembangunan berbasis hak juga meliputi persamaan dan keadilan, akuntabilitas, pemberdayaan dan partisipasi. (www.kruha.org diakses 20 Agustus 2014).

Implikasi pengakuan akan adanya hak atas air adalah memberikan tugas kepada negara untuk menyelenggarakan mekanisme sedemikian rupa sehingga akses masyarakat terhadap air dapat tersedia. Mekanisme ini harus diatur sehingga tidak memberikan peluang kepada negara untuk mengalihkan tanggung jawabnya kepada pihak-pihak lain. Konsekuensinya, tidak berarti bahwa setiap orang harus mendapatkan air secara gratis tanpa ada batasan jumlah penggunaan, yang akan memunculkan kemungkinan bagi mereka yang kuat untuk mendapatkan sumber daya air lebih banyak tetapi justru pengakuan hak atas air ini memberikan kesempatan kepada negara untuk melakukan pengaturan akan pembatasan-pembatasan tertentu kepada orang atau sekelompok orang tertentu demi memastikan bahwa hak atas air tiap-tiap orang harus tetap terpenuhi. Dengan kata lain, negara tidak bisa membiarkan pelaku bisnis misalnya karena kekuatannya ekonominya. Kemudian menguasai sumber daya air yang dapat dibelinya untuk dimanfaatkan bagi kepentingan bisnisnya semata. Peran negara justru memastikan bahwa air tersedia secara cukup bagi kebutuhan minimal sehari-hari. Tindakan negara untuk membiarkan bahkan memfasilitasi dengan perlindungan hukum tertentu bagi sekelompok bisnis untuk menguasai sumber daya air sementara masih banyak warganya yang belum mendapatkan air bagi kebutuhan minimal sehari-hari merupakan pelanggaran (www.kruha.org diakses 29 November 2014).

Penyediaan secara gratis dalam jumlah tertentu bagi masyarakat perlu dilakukan sebagai bukti nyata pengakuan negara atas hak atas air, dan pada saat yang bersamaan hal itu juga mengimplikasikan pembatasan kepemilikan sumber daya air agar tidak mengurangi 'kemampuan' negara untuk menyediakan air bagi warganya, paling tidak untuk mencukupi kebutuhan minimal seharihari, sehingga penyediaan secara gratis harus dipahami sebagaimana diuraikan di atas dan bukan sekadar gratis saja. 
Memotong pemahaman hanya sampai kata gratis saja tanpa menambahi dengan jumlah tertentu dan sekaligus pembatasan kepemilikan sumber daya air sangat menyesatkan, seolah-olah justru nantinya memberikan kesempatan kepada mereka yang mampu menguasai sumber daya air untuk segera mengambil dan menguasainya. Sekali lagi problemnya bukan pada implikasi air harus disediakan gratis atau tidak tetapi bahwa negara memiliki kewajiban untuk tidak saja penyediaan air bagi kebutuhan minimal sebagai tugas utamanya dalam pemenuhan hak atas air tetapi juga pembatasan bagi kepemilikan sumber daya air yang berimplikasi terhadap penurunan kemampuan negara untuk menyediakan pemenuhan hak atas air tersebut. (www. kruha.org diakses 29 November 2014).

Hak atas air, sebagaimana hakhak asasi manusia lainnya, menyiratkan adanya tanggung jawab dari negara untuk memenuhinya. Untuk itu, problemnya bukan kepada kesertamertaan bagi setiap warga negara untuk dapat memperoleh air tetapi lebih kepada adanya mekanisme yang tegas dan jelas bagimana negara akan melakukan upaya-upaya bagi ketersediaan air dan terutama langkah-langkah untuk menjamin akses tersebut.

Yang harus diperhatikan dalam menyikapi hal ini adalah, siapa pun penyedia airnya, hak atas air memberikan mandat bahwa penyedia air harus dianggap sebagai lembaga kepanjang-tangan negara. Dengan bahasa yang berbeda, penyedia air haruslah lembaga yang memiliki sifat dan karakteristik lembaga publik sama seperti lembagalembaga publik milik negara lainnya.

Beberapa konsekuensi yang bisa disebutkan jika lembaga penyedia air dilihat sebagai lembaga publik antara lain adalah: (a) lembaga tersebut terikat kepada prinsipprinsip keterbukaan informasi sebagaimana lembaga publik lainnya. Maka, tidak ada alasan bagi lembaga penyedia air untuk tidak membuka dokumen yang dimilikinya dengan alasan bahwa itu adalah rahasia perusahaan. Sebagai lembaga publik maka akses informasi terhadap dokumen yang dimilikinya menjadi kewajiban yang harus dipenuhi juga. (b) lembaga penyedia air juga harus bisa dikontrol melalui berbagai mekanisme publik yang ada. Wakil rakyat memiliki kewenangan untuk memeriksa dan mengawasi jalannya lembaga penyedia air ini. Demikian halnya juga dengan misalnya kebijakan untuk menaikkan tariff dan atau nilai keuntungan yang diharapkan. (c) lembaga penyedia air juga memiliki kewajiban untuk menjalankan kegiatannya sebagai pemenuhan hak atas air yang menjadi tanggungjawab negara. Dengan keterikatan semacam itulah maka pengelolaan lembaga penyedia air harus dijalankan (www.kruha. org diakses 29 November 2014).

Jika saja ketentuan-ketentuan yang harus dipenuhi sebagai lembaga publik harus dijalankan secara konsisten maka, perusahaan swasta akan berpikir lagi untuk terlibat di dalam penyediaan air sebagai konsekuensi pemenuhan hak atas air. Misalnya, kontrakkontrak yang akan ditandatangani harus bisa diakses oleh publik, pelaksanaan penyelenggaraan pemenuhan hak atas air yang dilakukan oleh swasta harus dilaporkan secara berkala kepada lembaga negara. Keuntungan yang diambil atau direncanakan akan diambil oleh perusahaan penyedia air tersebut harus bisa dibatasi oleh lembaga publik lain, terutama ketika negara masih menetapkan terjadinya subsidi terhadap tarif air yang ada (www.kruha.org diakses 29 November 2014).

Jadi, problem utamanya lebih kepada, pelibatan pihak swasta sebagai penyedia air tidaklah menghapuskan tanggungjawab pemerintah untuk memenuhi hak atas air yang dimiliki oleh rakyatnya. Kedua, seringkali dalam pelibatan swasta sebagai penyedia air, konsekuensi logis dari pelaksana tanggungjawab negara akan dihilangkan begitu saja, atas nama rahasia perusahaan. Hal ini kemudian menyebabkan akses masyarakat terhadap perusahaan penyedia air menjadi tertutup. Yang lebih memperparah adalah, karena ketertutupan atas nama rahasia perusahaan itu telah menyebabkan kontrak-kontrak yang ditandatangani bagi keterlibatan pihak swasta menjadi sangat berat sebelah sehingga menguntungkan perusahaan swastanya. Inilah yang kemudian menyebabkan para pejuang hak asasi manusia menolak pelibatan swasta yang demikian. (www. kruha.org diakses 29 November 2014).

Pengakuan air sebagai hak asasi manusia mengindikasikan dua hal; di satu pihak adalah pengakuan terhadap kenyataan bahwa air merupakan kebutuhan yang demikian penting bagi hidup manusia, di pihak lain perlunya perlindungan kepada setiap orang atas akses untuk mendapatkan air. Demi perlindungan tersebut perlu dipositifkan hak atas air menjadi hak yang tertinggi dalam bidang hukum yaitu hak asasi manusia. 
(Majalah Percik, Edisi III, 2010)

Manfaat dari ditetapkannya hak atas air sebagai hak asasi. Seperti misalnya (i) air menjadi hak yang legal, lebih dari pada sekedar layanan yang diberikan berdasar belas kasihan; (ii) pencapaian akses dasar harus dipercepat; (iii) mereka yang terabaikan menjadi lebih diperhatikan sehingga kesenjangan dapat berkurang; (iv) masyarakat dan warga yang termarjinalkan akan diberdayakan untuk berperan dalam proses peng ambilan keputusan; (v) negara menjadi lebih fokus pada pemenuhan kewajibannya karena dipantau secara internasional (Majalah Percik, Edisi III, 2010).

Berbicara tentang hak atas air sebagai hak asasi manusia, terdapat beberapa kelompok yang sangat terdampak oleh perubahan yang akan terjadi. Mereka terdampak terutama karena selama ini terabaikan haknya dan menjadi kelompok yang dengan berbagai alasan normatif dan legal tidak menjadi target penyedia layanan air minum.

Perempuan di banyak komunitas mendapat status yang lebih rendah dibanding pria. Mereka mendapat tugas mengumpulkan atau mencari air untuk kebutuhan rumah tangga. Data menunjukkan 70 persen dari 1,3 miliar penduduk yang sangat miskin adalah wanita (WHO, 2001). Riset menunjukkan bahwa rata-rata rumah tangga di Afrika menghabiskan 26 persen waktunya untuk mengumpulkan air, dan umumnya wanita lah yang menjalankan tugas ini (DFID, 2001). Kondisi ini menghalangi wanita bekerja, bahkan bersekolah. (Majalah Percik, Edisi III, 2010).

Kondisi air yang tidak memadai meningkatkan peluang anak-anak menderita penyakit. Sistem kekebalan mereka belum sepenuhnya terbangun. Anak-anak juga seringkali berbagi tugas dengan kaum perempuan sebagai pengumpul air. Akibatnya, di banyak negara anak-anak banyak yang tidak bersekolah. Pada suatu masyarakat tradisional sebenarnya masyarakat aslilah yang memanfaatkan sumber air tradisional. Namun, dengan berkembangnya suatu daerah, sumber air tersebut kemudian banyak yang tercemar atau dimanfaatkan melebihi kapasitasnya. Kondisi ini kemudian menjadikan mereka tidak dapat memenuhi kebutuhannya akan air.

Terlebih lagi dalam konferensi air dan lingkungan internasional yang diselenggarakan tahun 1992 di Dublin, Irlandia, melahirkan The Dublin Statement on Water and Sustainable Development (yang lebih dikenal de ngan Dublin Principles). Dublin Principles berisi empat prinsip yang harus dikedepankan dalam kebijakan dan pembangunan di sektor sumber daya air. Salah satu dari prinsip tersebut adalah Water has an economic value in all its competing uses and should be recognized as an economic good. (Miguel Solanes and Fernando Gonzalez-Villarreal, 1999:6).

Lahirnya the Dublin Principles, menyebabkan banyak lembaga internasional mereposisi kebijakan mereka di sektor sumberdaya termasuk Bank Dunia. Bahkan Bank Dunia kemudian mengambil peran sentral dalam mengembangkan dan mempromosikan pendekatan-pendekatan baru yang konsisten dengan Dublin Principles terutama memberlakukan air sebagai barang ekonomi. Dalam praktiknya lembaga keuangan internasional menempatkan reformasi sumberdaya air yang memberlakukan air sebagai barang ekonomi dalam satu paket kebijakan neo liberal yang lebih luas dan kebanyakan melalui structural adjustment program.

Lebih lanjut penguasaan negara atas air sebagai bagian dari kebutuhan yang paling mendasar dan hak asasi manusia semakin dipertegas dalam Undang Undang Dasar 1945 Pasal 28A: "Setiap orang berhak untuk hidup serta berhak mempertahankan hidup dan kehidupannya", Pasal 28D Ayat (1) Setiap orang berhak atas pengakuan, jaminan, perlindungan, dan kepastian hukum yang adil serta perlakuan yang sama di hadapan hukum dan pasal 28I ayat (4) yang menyatakan bahwa "perlindungan, pemajuan, penegakan dan pemenuhan hak asasi manusia adalah tanggung jawab negara terutama pemerintah. Permasalahannya tidak dijelaskan secara lebih lanjut tentang apa yang dimaksud sebagai kemakmuran rakyat, sehingga dimensi inilah yang didalam praktik sering diterjemahkan terlalu luas atau terlalu sempit oleh pembuat kebijakan, sehingga rentan menimbulkan konflik.

Sebagai sebuah layanan publik yang sangat mendasar, penyediaan air bagi masyarakat harus menjadi tanggung jawab negara sehingga harus dikuasai oleh negara, sesuai dengan pasal 33 UUD 1945. Pemenuhan hak atas air sebagai layanan publik dan tidak didominasi oleh swasta sekaligus menguatkan konsep pembangunan yang berkelanjutan 
juga sering dijabarkan dengan daya dukung lingkungan (carrying capacity). Secara umum, keberlanjutan diartikan sebagai contuining without lessening yang berarti melanjutkan tanpa aktivitas menguranginya. (Akhmad Fauzi dan Alex Oktavianus, 2014: 43). Dalam hal ini dapat dikatakan bahwa penguasaan negara atas air akan memberikan jaminan ketersediaan air bagi generasi mendatang. Privatisasi air meniscayakan adanya antitesa dari pembangunan berkelanjutan karena air didekati sebagai barang ekonomi. Pemenuhan hak atas air dengan berorientasikan kepentingan masyarakat dan melibatkan masyarakat dapat dijadikan modal sosial. Modal sosial yang merupakan norma dan jaringan kerja yang memungkinkan orang melakukan sesuatu secara bersama-sama. (Nasution, 2014:139).

Artikel ini berdasarkan hasil Penelitian Hibah Fundamental DIKTI dengan No. Kontrak Nomor: 139/LPPM.SP3/IV/2015.

\section{Simpulan dan Saran}

Kesimpulan yang dapat ditarik dari rangakaian diskurus tentang hak atas air adalah sebagai berikut:

Islam menuntut kita untuk mengelola dan mendistribusikan air secara adil. Sebab kita semua terhubung dengan air sebagai salah satu ciptaan Tuhan. Semua manusia memiliki hak yang sama atas air. Inilah makna Tauhid kesatuan Tuhan dan ciptaan Nya; sedangkan instrumen hukum internasional memandang pemenuhan hak atas air sebagai syarat mutlak untuk terciptanya standar hidup yang layak (adequate standard of living); dan berdasarkan hukum konstitusi negara (UUD 45) bahwa penguasaan negara atas air akan memberikan kesempatan yang lebih besar terhadap adanya keadlan dalam pemenuhan hak atas air

Penguasaan air oleh swasta memiliki orientasi kepada mendapatkan keuntungan sebesar-besarnya secara ekonomi. Fakta yang ditemukan penguasaan dan pengusahaan air tersebut telah membatasi akses masyarakat banyak terhadap air, sehingga pemenuhan hak atas air yang berorientasi kepada pemenuhan hak atas air sebagai suatu kebutuhan dasar (basic need) menjadi terabaikan, dan semakin menjauhkan pencapaian tujuan negara dalam menyejahterakan rakyatnya.

Hak atas air, sebagaimana hak-hak asasi manusia lainnya, memberikan kewajiban kepada negara untuk memenuhinya. Untuk itu, problemnya bukan kepada kesertamertaan bagi setiap warga negara untuk dapat memperoleh air tetapi lebih kepada adanya mekanisme yang tegas, dan jelas bagaimana negara akan melakukan upayaupaya bagi ketersediaan air dan terutama langkah-langkah untuk menjamin akses tersebut. Dengan demikian, kewajiban negara dalam hal hak atas air, yaitu menghormati (to respect), melindungi (to protect), dan memenuhi (to fulfill), dapat tercapai.

\section{Daftar Pustaka}

Abdul-Martin, Ibrahim, (2010), Greendeen, Inspirasi Islam dalam Menjaga dan Mengelola Air, Zaman, Jakarta.

Ahmadriswan Nasution, Eman Rustiadi, Bambang Juanda, Setia Hadi, (2014), Dampak Modal Sosial terhadap Kesejahteraan Rumah Tangga Pedesaan di Indonesia Volume 30 No. 2, hal. 137-148.

Akhmad Fauzi dan Alex Oktavianus, (2014), Pengukuran Pembangunan Berkelanjutan, Mimbar: Jurnal Sosial dan Pembangunan, Volume 30 No. 1, hal.42-55.

Amy Hardberger, (2006) "Whose Job Is It Anyway?: Governmental Obligations Created by the Human Right To Water", 41 Texal International Law Journal 533.

Benny D. Setianto, Ketika GTZ Melakukan Penyesatan Terhadap Hak Atas Air; Menyesatkan -Penyesat- Hak Atas Air, http://www. kruha.org/page/id/dinamic_ detil/13/132/Hak_atas_Air/Ketika_GTZ_ Melakukan_Penyesatan_Terhadap_Hak_ Atas_Air__Menyesatkan__Penyesat Hak_Atas_Air.html, diakses tanggal 29 November 2014.

Benny D. Setianto, Sesat Pikir Hak Atas Air, http://www. kruha.org/page/id/dinamic detil/13/129/Hak_atas_Air/Sesat_Pikir_ Hak_Atas_Air.htm/ diakses tanggal 20 Agustus 2014.

Catarina de Albuquerque, (2014), Realising the human rights to water and sanitation: $A$ Handbook by the UN Special Rapporteur Catarina de Albuquerque, Bangalore, India. UN Special Rapporteur on the human right to safe drinking water and sanitation.

Komnas HAM (2009), Komentar Umum Kovenan Internasional Hak Sipil dan Politik Kovenan Internasional Hak Ekonomi Sosial dan Budaya, Komnas HAM, Jakarta.

Majalah Percik: Media Informasi Air Minum dan Penyehatan Lingkungan, (2010), Hak atas Air Sebagai Hak Asasi Manusia, Edisi III, Kelompok Kerja Air Minum dan Penyehatan Lingkungan (Pokja AMPL), Jakarta

Maude Barlow dalam Vandhana Shiva, (2003), Water Wars: Privatisasi Profit dan Polusi, 
Yogyakarta, Insist Press,

Miguel Solanes and Fernando GonzalezVillarreal, (1999), The Dublin Principles for Water as Reflected in a Comparative Assessment of Institutional and Legal Arrangements for Integrated Water Resources Management, Stockholm, Sweden, Global Water Partnership/ Swedish International Development Cooperation Agency.

United Nations Water Conference, (1977) (Resolutions), http://ielrc.org/content/ e7701.pdf diakses tanggal 2 Mei 2015

Wiwik Harjanti, (2009), Hak Atas Air Dalam Konstitusi Negara dan Pengelolaannya di Indonesia (Right of Water in Indonesian Constitution and its Managements),
Risalah Hukum: Jurnal Hukum, Fakultas Hukum Universitas Mulawarman, Vol 5, No. 2.

Instrumen Hukum:

Undang-Undang Dasar 1945

The International Covenant on Economic, Social and Cultural Rights (ICESCR)

The Convention on the Elimination of all Forms of Discrimination Against Women (CEDAW) 1979

Convention on the Rights of the Child (CRC) 1989.

Undang-Undang Nomor 39 Tahun 1999. Tentang Hak Asasi Manusia 